\title{
Zyskiwanie samowiedzy poznawczej jako proces edukacyjny
}

\begin{abstract}
Abstrakt
Artykuł jest próbą przybliżenia podejścia refleksywnego w odmianie auto/biograficznej. W tym kontekście interpretacji poddane zostały dwie reprezentatywne dla tego podejścia wypowiedzi zamieszczone w tomie 4. czasopisma "Nauki o Wychowaniu. Studia Interdyscyplinarne” („NOWIS”). Na innym poziomie tekst ukazuje problem dystansu i bliskości występujący między różnymi ujęciami stosowanymi w badaniach poświęconych edukacyjnym wymiarom biografii.
\end{abstract}

Słowa kluczowe: refleksywność, narracja, podejście auto/biograficzne, etnografia życia, kryptoautobiografia, badania edukacyjne, Wojciech Józef Burszta, Iwona Kabzińska.

\section{Gaining Cognitional Self-Awareness as an Educational Process}

\begin{abstract}
The article is an attempt to present the reflexive approach in its auto/biographic form. In this context, two representative reflexive essays featured in Volume 4 of the periodical "Educational Sciences. Interdisciplinary Studies" ("NOWIS") are interpreted. Additionally, the text shows the problem of distance and proximity appearing among different perspectives of conducting educational-biographic research.
\end{abstract}

Keywords: reflexivity, narrative, auto/biographic approach, ethnography of life, cryptoautobiography, educational research, Wojciech Józef Burszta, Iwona Kabzińska.

\footnotetext{
* Uniwersytet Łódzki, Wydział Nauk o Wychowaniu, Katedra Badań Edukacyjnych.
} 
Kiedy z górą rok temu odbywaliśmy w gronie współredaktorskim pierwsze konsultacje poświęcone warstwie merytorycznej tematycznego tomu "NOWIS” (nr 1 (4) 2017) pt. Edukacyjne wymiary badań biograficznych, skłaniałem się ku przyjęciu rozwiązania pozwalającego na uwypuklenie charakterystyczności perspektyw badań biograficznych rozwijanych na Wydziale Nauk o Wychowaniu Uniwersytetu Łódzkiego. Wysuwając podobną propozycję, opierałem się na poglądzie, iż różnolitość, z jaką mamy do czynienia w podejściach do badań biograficznych preferowanych przez współredaktorów tej publikacji, Elżbietę Kowalską-Dubas, Danutę Urbaniak-Zając i Marcina Kafara ${ }^{1}$ ostatecznie nie stanowi przeszkody, lecz atut w konstruowaniu czegoś na kształt uwspólnionej metaperspektywy poznawczej, przy jednoczesnym zachowaniu odrębności ujęć najbliższych każdemu z nas z osobna. Mówiąc o „uwspólnionej metaperspektywie poznawczej”, oczywiście nie odnosiłem się do zintegrowanego programu badawczego, który znajdowałby przełożenie np. na konkretne, uspójnione rozstrzygnięcia teoretyczno-metodologiczne czy metodyczne; zależało mi raczej na stworzeniu warunków sprzyjających ujawnieniu się podzielanego poczucia operowania w zbieżnym horyzoncie praktyk poznawczych, horyzoncie na tyle pojemnym, iż zdolny byłby on pomieścić artykuły nawiązujące zarówno do krytyczno-teoretycznego ujęcia tematu biografii w wydaniu Danuty Urbaniak-Zając, postrzeganiu biografii w odniesieniu do rdzenia andragogicznego (z nim najmocniej identyfikuje się Elżbieta Dubas), a wreszcie zmierzeniu się z biografią na sposób refleksywny, za czym optuję ja sam.

„Czy takie «podzielane poczucie» ostatecznie udało się nam osiągnąć? W czym miałoby się ono przejawiać?” - zastanawiałem się, dokonując podsumowań związanych z pracą nad prezentowaną Czytelnikowi publikacją. Na te pytania nie znajdowałem prostych odpowiedzi, wszelako droga, jaką podążałem, wiodła ku pewnym nawracającym wątkom, które postaram się teraz pokrótce zrekonstruować, szczególny nacisk kładąc na pojawiające się w nich akcenty biograficzno-edukacyjne.

Wspomnieliśmy we Wprowadzeniu od redaktorów tomu, że każdy z nas zaprosił „do przygotowania artykułu Autorów i Autorki należących do określonej - mniej czy bardziej spójnej - wspólnoty myślowej, w której sam się sytuuje” (s. 8)². Niezbywalną cechą wspólnot jest ich rys społeczny. W przypadku wspólnot myślowych (równie dobrze można by tutaj mówić o „wspólnotach dyskursu” (Wejland 2010a) bądź „kolektywach myślowych” (Fleck 1986)) ów rys społeczny swą specyfikę zyskuje poprzez zorientowanie na rozwijane w czasie podobne widzenie świata, uwrażliwienie na wybrane jego aspekty, co stanowi bazę do przygotowania,

\footnotetext{
1 Różnolitość ta znakomicie uwidacznia się w profilu publikacji, jaki wypracowujemy na przestrzeni ostatnich kilkunastu lat (por. m.in. Dubas 2015a, 2015b, 2014a, 2014b, 2011, 2009; Kafar 2016, 2013a, 2013b, 2011, 2004; Urbaniak-Zając 2014, 2011, 2009).

2 Dla cytatów zaczerpniętych z aktualnego tomu „NOWIS” stosuję uproszczony wariant zapisu, podając wyłącznie numer strony, z której pochodzi dany ustęp; w przypadku pozostałych pozycji posługuję się standardowym zapisem bibliograficznym.
} 
a następnie posłużenia się daną wykładnią rzeczywistości. Warto pamiętać, iż umiejscawiane $\mathrm{w}$ tak pojmowanym kontekście naukowe/akademickie wspólnoty myślowe są zaledwie ułamkiem niezliczonej liczby wspólnot myślowych, z jakimi mamy do czynienia, występując w rolach depozytariuszy światów społeczno-kulturowych. Każdy z tych światów posiada własną myślową oś, będącą odzwierciedleniem aktualnego stanu świadomości zbiorowej, co ważne, świadomość ta znajduje zakorzenienie także w podmiotach jednostkowych, wykazujących się dzięki niej odpowiednio sprofilowanym systemem przekonań.

Gdybym miał pokusić się o wyłuszczenie składowych konstytutywnych dla naukowej/akademickiej „wspólnoty myślowej, w której sam się sytuuj[ę]”, a której przekonania zaowocowały m.in. powstaniem kilku tekstów pomieszczonych w tomie pt. Edukacyjne wymiary badań biograficznych ${ }^{3}$, to na pierwszym planie niewątpliwie znalazłoby się przekonanie o podmiotowej naturze praktyk naukowych. Naukę da się postrzegać jako zestaw narzędzi i działań stosowanych w celu dotarcia do zobiektywizowanej prawdy o rzeczywistości lub też jako integralną część owej rzeczywistości - wybór drugiego z wyodrębnionych podejść niezbywalnie wiąże się z dopuszczeniem do głosu prawdy osobowej, międzyosobowej, wewnątrzwspólnotowej i międzywspólnotowej; wszystkie one - brane łącznie zakładają zaś udział $w$ praktyce naukowej człowieka, czyli kogoś, kto albo samodzielnie, albo też wespół z innymi ludźmi wpływa na to, kim jest on sam oraz jakq postać przyjmuje (naukowy) świat, do którego należy.

Podmiotowa natura praktyk naukowych uzewnętrznia się i zarazem jest uchwytna za pomocą wielorakich środków. Jednym z nich jest poruszanie się w sferze refleksywnej, inaczej - samozwrotnej, wymagającej od podmiotu (indywidualnego i zbiorowego) sproblematyzowania tego, co wcześniej wydawało się oczywiste. Refleksywność to nic innego jak docieranie do świadomości wyższego rzędu, do „świadomości bycia świadomym” (ang. conciousness of being conscious), by użyć klasycznego już dziś sformułowania Barbary Myerhoff i Jaya Ruby’ego (1982: 1).

Akty refleksywne bardzo często przybierają formę auto/biograficzna o wielorakim zabarwieniu znaczeniowym. W grę wchodzi wtedy przesunięcie punktu ciężkości na stronę świadomego swej refleksywności podmiotu jednostkowego. $\mathrm{Na}$ poziomie praktyki naukowej ów podmiot może być podmiotem świadomym, ale „milczącym” (świadomie milczącym), może być refleksywny „na własne potrzeby” (wygłuszenie refleksywne widać np. w pisaniu przez badaczy dzienników bez zamiaru ich upubliczniania, poezji wprost poświęconej przedmiotowi badań lub

\footnotetext{
${ }^{3}$ Są to (podaję w kolejności alfabetycznej według nazwisk poszczególnych autorów): W podwojonym cieniu. Zapiski z etnografii życia Wojciecha Józefa Burszty, „Nienawidzę tej szkoły”. O odrzuceniu, niezrozumieniu i o tym, jak wiele zależy od człowieka Iwony Kabzińskiej, Wokół transgeneracyjnych biografii naukowych. Zaczynając od Heleny Radlińskiej i Kazimiery Zawistowicz-Adamskiej Marcina Kafara i Izabeli Kamińskiej-Jatczak oraz Badacz wobec doświadczeń dorosłych w kontekście biograficznej perspektywy badawczej Joanny Golonki-Legut i Martyny Pryszmont-Ciesielskiej.
} 
pozostającej z nim w „podskórnych” relacjach, czy innych, alternatywnych w odniesieniu do myślowego „głównego nurtu” form ekspresji, takich jak powieść, akcydentalne parateksty, prywatna korespondencja itp. ${ }^{4}$ ) lub podmiotem jawnie objawiającym światu refleksywne nastawienie. Przejawy otwartej refleksywności znajdują się w tekstach, w których „ja” badacza stanowi nieodstępny element procesu badawczego, proponowanej teorii, podejścia, perspektywy itd., także tych pozostających jeszcze $\mathrm{w}$ fazie dookreślania.

W inicjowanych przeze mnie pracach, przygotowanych do naszego numeru skala refleksywności jest różna, różne są też sposoby jej wyrażania. Poniżej skupię się na „przybliżeniu” dwóch artykułów noszących wyraźne refleksywne znamiona. Spróbuję uruchomić interpretacyjny warsztat w celu wykonania ćwiczenia, którego zadaniem będzie uzmysłowienie Czytelnikowi, w czym tkwi jądro demonstrowanego podejścia.

Należący do tej puli artykuł Wojciecha Józefa Burszty pt. W podwojonym cieniu. Zapiski z etnografii życia stanowi próbę ukonstytuowania alternatywnej etnografii, nazywanej przez Autora właśnie „etnografią życia”. W wariancie tu prezentowanym $^{5}$ ta ostatnia zasadza się na założeniu, że od życia etnografa nieodłączne jest etnograficzne spojrzenie na świat. Na pierwszy rzut oka takie stwierdzenie może wydawać się dość banalnym, wszelako - przy bliższym w nie wglądzie - odsłania treści nadzwyczaj poważne. „Mam pewność, że to, co zwiemy życiem, a co wiąże się z poczuciem, że wiele rzeczy - przeszłych i obecnych - dzieje się jednocześnie, nie jest jedynie mało istotnym dodatkiem do zawodowej biografii, ale istotnym wymiarem jej kształtu i profilu" - pisze Burszta (s. 161). Tym samym składa on deklarację przyjęcia epistemologicznej pozycji, dopuszczającej zazębianie się, więcej nawet przenikanie i to przenikanie ciągłe dwóch odrębnych porządków: porządku życia pozazawodowego oraz porządku życia akademickiego; warunkują one siebie nawzajem, nadając jednocześnie „kształt i profil” budowanej na ich fundamentach tożsamości osobowej.

Centralną kategorią, jaką posługuje się w swoich nasączonych intymnością „wiwisekcyjnych” (sic!) rozważaniach Wojciech Józef Burszta, jest czas rozumiany w ślad za Paulem Ricoeurem - jako ściśle spleciony z opowieścią „o sobie samym jako innym" (Ricoeur 2005). Ten inny - człowiek i etnograf pozostający człowiekiem - dzielnie staje w szranki z własnymi doświadczeniami, aby, rozwiązując ułożoną z nich przez los szaradę, odpowiedzieć na pytanie „kim jestem dzisiaj” (s. 160)? W Zapiskach z etnografii życia główny bohater z jednej strony wierny jest chronologii zdarzeń, z drugiej strony celowo, jak się zdaje, tę chronologię burzy po

\footnotetext{
${ }^{4}$ Bliższe omówienia tego tematu wraz z przykładami znajdziemy m.in. w Bowen (1954); Burszta (1994); Friedrich (1979, 1978); Mead (1966); Klimaszewska (1976); Powdermaker (1966); Rose (1982).

${ }^{5}$ Interesującym zabiegiem byłoby niewątpliwie przyjrzenie się projektowi „etnografii życia” Burszty przez pryzmat poznawczego spowinowacenia tegoż pomysłu z propozycją Dana Rose'a, który przed laty mówił o „przeżywaniu etnograficznego życia” (ang. living the etnhnographic life) (Rose 1990) czy, na gruncie polskim, wizją Dariusza Czai, antropologa postulującego odejście od badania „kultury” na rzecz badania „życia” (Czaja 2002).
} 
to, by mieć możliwość przemieszczania się między odrębnymi rodzajami czasu; w efekcie, to, co „linearne”, spotyka się z tym, co „koliste”, a więc zabarwione mitem. Punktem wyjścia do rozpoczęcia opowieści jest zbliżająca się 60. rocznica urodzin Autora (naprowadzenie Czytelnika na skojarzenia z magią liczb ${ }^{6}$ wydaje się w tym wypadku chyba aż nazbyt oczywiste). Potraktowana ona została jako pretekst do wyruszenia na narracyjną wyprawę ku przeszłości, wypełnionej bagażem przeżyć układających się w znaczący formatywny wzór. Tę interpretacyjną okoliczność nicuje ściągnięta z pamięciowego „stryszku” badacza metafora „podwojonego cienia”, cienia, którego smugi rzucają, odpowiednio, szara rzeczywistość późnej epoki PRL (to okres dorastania i młodości Wojciecha Józefa Burszty) oraz, w innym wymiarze, dom rodzinny, w dzielonych z nami wspomnieniowo-literackich odczuciach przedstawiany jako na wskroś i nieomal „od zawsze” przesiąknięty lękami o jego trwałość.

Refleksywny rys „Wojciecha Józefa Burszty” osadzony jest głęboko w dramacie życia7, sprowadzając się do podjęcia wyzwania konfrontowania się z nieuchronnością upływu czasu i przydającymi mu egzystencjalnego ciężaru jego skutkami. „Cień podwojony to walka ze smutkiem", a etnografia życia - stosowana w odniesieniu do doświadczenia jednostkowego - „byłaby niczym innym jak swoistym raportem z tych zmagań" - czytamy (s. 160; wyróżnienie moje - MK).

Słowo „wyzwanie”, przy uwzględnieniu dla niego rozszerzonego zakresu konotacji semantycznych, prowadzi nas w stronę przełamywania tradycyjnego dyskursu etnograficzno-etnologicznego (klasyczna etnologia, przypomina Ewa Nowicka, uciekając się do aforystycznego języka Ioana M. Lewisa, zwykła zajmować się ludami, nie ludźmi (Nowicka 2006: 21)); stawia zarazem autora W podwojonym cieniu - przynajmniej do pewnego stopnia - w roli rewelatora-konwertyty ${ }^{8}$ (Wej-

\footnotetext{
${ }^{6} \mathrm{Na}$ temat magii liczb i jej spowinowacenia ze stereotypem patrz Benedyktowicz (2000: 83-85).

${ }^{7}$ Zwrotu „dramat życia” używam w duchu filozoficznym, pozostając w kręgu metaforyki Tischnerowskiej (Tischner 2006).

${ }^{8}$ Pozycję „rewelatora” wyodrębnia Andrzej P. Wejland, który stawiając ją obok dwóch innych epistemologicznych pozycji - nowicjusza i eksperta - tłumaczy, co znaczy „spojrzeć na świat jak antropolog”. Wedle modelu Wejlandowskiego, wszystkie trzy pozycje odpowiadają osobnym rodzajom usytuowania pojedynczego badacza-antropologa względem traktowanej przez niego jako grupa uczestnictwa, odniesienia, bądź aspiracji antropologicznej wspólnoty. Wejland (2016: 38) wyjaśnia: „(...) wyrażenie «spojrzeć na świat jak antropolog» może wskazywać na potrzebę albo konieczność antropologicznego, ale nieznanego lub niepraktykowanego dotąd (bądź niepraktykowanego szerzej) sposobu patrzenia na świat - przez antropologów. Pozycja, z jakiej się to wskazanie czyni, to pozycja rewelatora. Rewelator jest zazwyczaj ekspertem, choć mógłby nim być również nowicjusz uzurpator. Rewelator - na podstawie krytycznej diagnozy - objawia sposób wyjścia z niemocy, zapaści, kryzysu, proponując wynalezioną przez siebie nową antropologię - z jej bystrym, widzącym wreszcie świat antropologicznie, okiem. (...) Ponieważ rewelator przypisuje sobie dar widzenia przyszłości (lub «widzenia na zapas»), rozpoznając ścieżki, które wiodą antropologię ku przepaści (albo zapaści) nie boi się stanowczej retoryki - retoryki profetycznej, przewidującej i zarazem napominającej". Co ważne, retoryka ta nigdy nie jest zawieszona w bezosobowej próżni. Rewelator nadzwyczaj chętnie odwołuje się zatem do własnych doświadczeń, przyjmując tym samym nastawienie autobiograficzne, gdzie dominuje postawa wyzwania. „Wyzwanie rzucone "czytelnikowi antropologicznemu», czy też czytelnikom - całej wyobrażonej wspólnocie antropologów albo wspólnocie konkretnej, wskazanej z imienia lub za pomocą dość jednoznacznej deskrypcji - przeważa nad świadectwem i wyznaniem w autobiografii pisanej (lub mówionej) z pozycji
} 
land 2016). Elżbieta Dubas, przygotowując część Od redaktorów tomu, zatytułowaną Edukacyjny wymiar badań biograficznych $w$ ujęciu andragogicznym, poczyniła znamienną uwagę, stwierdzając, że odmienność podejść etnograficzno-antropologicznego i andragogicznego do badań biograficznych „nie wyklucza (...) obecności punktów wspólnych” (s. 9). Sytuacja jest o tyle interesująca, iż tekst Wojciecha Józefa Burszty, patrząc na niego ze środka obowiązujących we wspólnocie antropologiczno-etnograficznej czy kulturoznawczej dominujących perspektyw badawczych, zasadnie mógłby zostać potraktowany za pracę w dużej mierze odstępczą ${ }^{9}$. Dla kogo w takim razie ten artykuł został napisany? Kto powinien go przeczytać, chcąc czerpać z niego pożytek? I - w konsekwencji należałoby się zastanowić jakiego rodzaju miałby to być pożytek?

Z pewnością nie dokonam przełomowego odkrycia, dzieląc się spostrzeżeniem, iż teksty takie jak $W$ podwojonym cieniu. Zapiski $z$ etnografii życia pisane są $\mathrm{w}$ równym stopniu dla innych co dla siebie. Często, o ile nie zawsze, to ich twórcy stają się pierwszymi i najważniejszymi odbiorcami własnych dzieł. Należy podkreślić, że językowo wyszlifowane, gotowe do upublicznienia wersje np. Bursztologicznych wyznań stanowią produkt finalny - pozostanę przy nomenklaturze Ricoeurowskiej - złożonego procesu uczenia się własnego charakteru ${ }^{10}$, za sprawą narracyjnie wykazywanych walorów troski o siebie (Ricoeur 2005: 270), walorów wyłaniających się z tła przedzierzgniętych w opowieść wybranych kolei życia.

Troska o siebie w przypadku Wojciecha Józefa Burszty polega na próbie zrozumienia siebie poprzez wyznaczenie narracyjnej mapy pozwalającej zachować (Odzyskać? Wzmocnić?) tożsamościową spójność. „Ludzkie życie kieruje się zasadą nieoznaczoności. Jedyne, co jest pewne na tym świecie, to potrzeba jego opowiedzenia" - wyrokuje autor omawianego eseju (s. 162). Instruktywna w kwestii nieprzewidywalności źródeł naukowej wyobraźni jest ufająca prawdzie tej opowieści wiedza, że oto ścieżka do uprawiania Bursztologicznej odmiany etnografii/antropologii wiedzie przez dziecięco-młodzieńcze pola doświadczeń, których kwintesencja zawiera się $\mathrm{w}$ niepozostawiającym interpretacyjnych wątpliwości wyznaniu: „mam (...) pewność owego momentu kluczowego, który sprawił, że wybrałem taką a nie inną drogę życiową. Bo - wybrałem ją dla Rodziców, Ojca przede wszystkim, dlatego, by - jednocześnie - powstrzymać upływ czasu i zatopić się w jego uwodzicielskim nurcie" (s. 161).

\footnotetext{
rewelatora” - powiada Wejland (tamże: 39), nawiązując do znanej koncepcji „trójkąta autobiograficznego" Małgorzaty Czermińskiej (2000).

${ }^{9}$ Pomimo to albo właśnie z powodu tego, że Burszta zdaje sobie sprawę z faktu wykraczania poza utarte schematy opisowe i analityczno-interpretacyjne wypełniające antropologiczny mainstream, nie rezygnuje on z nazewnictwa stosowanego w najbliższej mu sferze naukowej, mówi o „etnografii życia”, a nie dajmy na to - „psychoanalizie życia”. To posunięcie wyraźnie obliczone jest na intelektualną prowokację, nie zaś posiłkowanie się konformistycznymi patentami, co tylko potwierdza jego rewelatorską proweniencję.

10 Burszta nazywa to uchwyceniem momentu, „który sprawia, że sam sobie jawię się jako obiekt stabilny" (s. 159).
} 
I żeby domknąć wątek tego, kto miałby znajdować pożytki w lekturze opowieści w stylu Bursztologicznym, ponownie sięgnę po słowo „wyzwanie”. Burszta rzuca wyzwanie stanowiącej dla niego pierwszoplanową płaszczyznę identyfikacji profesjonalnej wspólnocie etnograficzno-antropologicznej. Kładąc na szali swój niewątpliwy autorytet teoretyka kultury, pokazuje, jak da się - wprowadzając osobiste doświadczenia na wciąż niezwyczajną ich obecności publiczną scenę nauki etnologicznej - uruchamiać dyskurs, który ma realną szansę stać się tutorem ${ }^{11}$, ma szansę uczyć nas, co znaczy wcielić w życie zasadę „narracyjnej jedności” (MacIntyre 1996). To, że takie w dosłownym tego wyrazu edukacyjne zalążki faktycznie tkwią w Zapiskach z etnografii życia dobitnie potwierdza następujący fragment recenzji wydawniczej:

Pod wpływem lektury recenzowanego tekstu uświadomiłam sobie istnienie cienia, w którym żyję od lat, coraz mocniej determinującego moją biografię. Czy cień jest obecny w życiu każdego człowieka? Czy każdy ma świadomość tej obecności? Jak radzimy sobie z naszymi cieniami? Czy szukamy „przesłoniętego” światła, czy pozostajemy w mrokach? Jakie są efekty naszych zachowań? Jaki wpływ mają na nas i tych, z którymi połączył nas Los? ${ }^{12}$.

To pytania, na które, jak sądzę, wielu z nas poszukiwać będzie odpowiedzi po zapoznaniu się z opowieścią W podwojonym cieniu. Zapiski z etnografii życia.

Inaczej brzmiący refleksywny tenor odzywa się w artykule pt. „Nienawidzę tej szkoły”. O odrzuceniu, niezrozumieniu i o tym, jak wiele zależy od człowieka, zaprezentowanym przez Iwonę Kabzińską. Jego wydźwięk jest dwudzielny. Dla postronnego Czytelnika sens prowadzonych dociekań wyczerpuje się w obrębie problemu wyobcowania dotyczącego dzieci odbiegających od przyjętych w realiach polskiej szkoły norm zachowaniowych. Mowa o kulturowych odmieńcach, uosabianych m.in. przez dzieci wykazujące się cechami skazującymi je na istnienie w środowiskowym odosobnieniu. Jednakże dla mnie jako kogoś, kto zna szerszy korpus prac Profesor Iwony Kabzińskiej (w tym także prac jeszcze niepublikowanych), przede wszystkim zaś zna background ich powstania, jasnym jest, że poza „oczywistym” wymiarem toczonych rozważań, mamy tutaj do czynienia z wymiarem „nieoczywistym”, któremu proponuję przydać miano kryptoautobiografii ${ }^{13}$. Najzwięźlej rzecz ujmując, chodziłoby o to, że Iwona Kabzińska myśląc i pisząc o stanie nadwrażliwości oraz kulturowo-społecznych mechanizmach, jakim podlegają ludzie

\footnotetext{
11 Na temat „dyskursu jako tutora” patrz Wejland (2010a).

12 Recenzja została przygotowana zgodnie z zasadą anonimowości. Nazwisko recenzenta pozostaje do wiadomości Redakcji „NOWIS”.

13 Terminem „kryptoautobiografia” po raz pierwszy posłużyłem się w artykule pt. Zwroty zapoznane zwrot dokonany. Autobiografia $w$ myśleniu etnograficznym $i$ antropologicznym (Kafar 2010), gdzie analizowałem przypadek biografii naukowej szkockiego antropologa, Victora W. Turnera.
} 
nadwrażliwi, myśli i pisze, uruchamiając filtr własnych doświadczeń. Przygotowując moją wypowiedź, skorzystałem z eseju naukowego popełnionego przez Autorkę z górą dekadę temu. Nosi on tytuł Sąsiedztwo ciszy $i$ hałasu i zaczyna się całkiem nietypowo - od zwierzeń:

Coraz bardziej męczy mnie życie w wielkim mieście, w „blokowisku”. Chciałabym uciec od nerwowego pośpiechu i niemal wszechobecnego hałasu. Zamykam oczy. Próbuję przywołać w myślach cudowną, kojącą, ciszę mongolskich stepów, lasów i gór Ałtaju, wieczorną ciszę wiosek ukraińskiego Podkarpacia ${ }^{14}$, ostępów Puszczy Nalibockiej, spacerów po plaży... Tęsknię do ciszy ogrodu, który otulał dom mego dzieciństwa. Dom z ogrodem, z dala od miejskiego zgiełku, pojawia się w marzeniach, które nigdy się nie spełnią. Może dlatego są tak piękne i jednocześnie tak bardzo bolesne. Przyklękam samotnie w pustym kościele. Nie potrafię powstrzymać potoku słów, galopady myśli, hałasu „świata”. Wychodzę z dotykiem Ciszy w sercu.

Nieco dalej na tej samej stronie czytamy:

Dla mnie hałas to ten rodzaj dźwięków, od których chciałabym uciec, które nie pozwalają zasnąć, skupić się, zagłuszają myśli i rozmowy, które denerwują, drażnią, niepokoją, męczą, sprawiają ból, pojawiają się nieproszone, wbrew mej woli, zabijając ciszę (Kabzińska 2007: 117).

Czytelniku, czy podpisałbyś się pod zacytowanymi właśnie frazami? Czy mógłbyś stać się ich Autorem, choćby tylko wirtualnym? Jeżeli odpowiedź jest twierdząca, zapewne także i Ty należysz do plemienia „nadwrażliwców”, podobnie jak Pani Iwona, Krzysiu, czyli chłopiec z podejrzeniem ADHD, służący za pierwowzór głównego bohatera „Nienawidzę tej szkoły”..., a także będący bohaterami drugiego planu w tej samej publikacji Ted Zeff (autor książki pt. Być nadwrażliwym i przetrwac) i - przywoływany przez Zeffa - Jay.

„Książkę Zeffa czytałam kilkakrotnie ${ }^{15}$ - przyznaje Iwona Kabzińska w „Nienawidzę tej szkoły”... i dodaje: Jeden z jej bohaterów - Jay, odrzucony przez kolegów, nauczycieli i najbliższą rodzinę z powodu zachowań wynikających z jego nadwrażliwości, stał mi się szczególnie bliski" (s. 138). W kolejnym podrozdziale, gdzie szkicowana jest postać Krzysia, ponownie napotykamy opis szczególnej, zapośredniczonej więzi, istniejącej między Autorką a interesującym ją dzieckiem:

\footnotetext{
${ }^{14}$ Iwona Kabzińska prowadziła badania etnologiczne m.in. w Mongolii oraz na terenach Białorusi, Litwy i Ukrainy.

15 Autorka do książki tej nawraca w dwóch innych artykułach. Pierwszy z nich pt. Nadwrażliwi marginalizowana mniejszość kulturowa, ukazał się w 2012 r. (Kabzińska 2012), drugi pt. Nadwrażliwi kulturowi odmieńcy został złożony do druku w czasopiśmie „Etnografia Polska”.
} 
Często myślę o chłopcu, o którym wielokrotnie opowiadała mi koleżanka - synu jej siostrzenicy. Opowieści te były pełne emocji. Słuchałam ich z uwagą, z przejęciem. Nie poznałam osobiście ich bohatera, stał się jednak dla mnie kimś ważnym. Wyobrażałam sobie, jak trudne były jego doświadczenia i jak bardzo musiał być samotny. Interesował mnie jego los. Współczułam jemu i jego rodzicom. Często o niego pytałam. Koleżanka przekazywała mi to, co usłyszała od jego mamy i babci, rozmawiając z nimi przez telefon lub podczas spotkań w rodzinnym gronie (s. 139).

Zdecydowałem się przytoczyć powyższe fragmenty, gdyż ujawniają one istotę podejścia badawczego uskutecznianego przez Iwonę Kabzińską. To podejście zasadza się na imperatywie rozkładania ciężaru poznawania między poznawanie Siebie a poznawanie Drugiego - człowieka przypisanego do obrzeży społecznej struktury. Nie mam wątpliwości, że antropologia w wydaniu Kabzińskiej jest antropologią dwuwektorową. Rozpoczyna się bowiem od wglądu we własną duszę, po to, by uruchomione tam pokłady empatii (wiemy już, że ich źródłem jest „nadwrażliwość”) pozwoliły badaczce zatopić się w duszę Innego - „Krzysia”, „Jaya”, „Teda”... Jednocześnie, wszelki bez wyjątku akt rozpoznania Tego Innego, jak ująłby to Ryszard Kapuściński (2006), przekształca się w akt rozpoznania Siebie. W „kulturowych odmieńcach” (przybliżany kontekst zdecydowanie pozbawia to określenie pejoratywnych zabarwień) pokroju Teda, Krzysia czy Jaya można przeglądać się niczym w lustrze tak długo, jak długo w żyłach nas samych płynąć będzie „krew odmieńca”.

Jeśli przyjęte przeze mnie tropy interpretacyjne są trafne, trafnym jest również traktowanie „Nienawidzę tej szkoły”... - skorzystam z potencjału sensotwórczego zawartego w neologizmie zaproponowanym przez Michała Pawła Markowskiego - jako tekstu sobąpisanego ${ }^{16}$. Pamiętać należy, że Iwona Kabzińska uznawana jest w środowisku antropologicznym za wybitną znawczynię badań biograficznych, doskonale zatem wie, na czym polega stosowanie przez narratorów przesłonięć. Jawna warstwa opowieści (historie Krzysia, Jaya i Teda) poprzez głęboko świadomy odautorski zabieg utożsamienia- $z^{17}$ („Jay, odrzucony przez kolegów, nauczycieli i najbliższą rodzinę z powodu zachowań wynikających z jego nadwrażliwości, stał mi się szczególnie bliski”, „Często myślę o chłopcu, o którym wielokrotnie opowiadała mi koleżanka (...) Nie poznałam osobiście ich bohatera, stał się jednak dla mnie kimś ważnym”) kolaboruje albo może lepiej powiedzieć - pozostaje w symbiozie z warstwą niejawną, „kryptoautobiograficzną”. Kiedy Pani Iwona pisze o tym, że

\footnotetext{
${ }^{16}$ Markowski posługuje się słowem „sobąpisanie” dokonując przekładu użytej przez Michela Foucaulta francuskiej frazy l'écriture de soi. Tłumacz korzysta przy tej okazji ze swych literaturoznawczych kompetencji, szukając inspiracji translatorskich w twórczości Edwarda Stachury, u którego znajdziemy piękny poetycki zwrot „życiopisanie” (Foucault 1999: 303, przyp. 1).

17 Kwestię „utożsamienia-z”, lub „identyfikacji-z” osadzam w obrębie rozpatrywanego przez Paula Ricoeura (2005: 263 i n.) zagadnienia tożsamości narracyjnej, ściślej - uwidacznianych na jego tle problemów łączenia się literatury/opowieści i rzeczywistego życia.
} 
wyobraża sobie, jak trudne musiały być doświadczenia Krzysia i „jak bardzo musiał być samotny", nie tylko, moim zdaniem, myśli z opowieściq tego bohatera, wcześniej ubierając ją w określoną narracyjną szatę (Czy to nie ona wyposaża $\mathrm{w}$ drugie, sfikcjonalizowane życie realnie żyjącej osoby?), ale też czuje z niqį, co znaczy ni mniej, ni więcej tylko odwołanie się do doświadczeniowego pokrewieństwa. Tak oto historia Krzysia, lecz także każdego innego „nadwrażliwca” staje się historią otwierającą szuflady pamięci umysłu oraz ciała Iwony Kabzińskiej i odwrotnie - jej doświadczenia, przeżywane za każdym razem od nowa, gdy do głosu dochodzi opowieść Drugiego, wpisują się w otwarty ciąg doświadczeniowo-opowieściowej sukcesji (w języku Elżbiety Dubas mówilibyśmy tu o uczeniu się z własnej biografii i biografii innego (por. Dubas, Świtalski 2011a, 2011b), uczeniu się „poprzez historie, opowieści, a także spostrzegani[u] samego procesu uczenia się jako procesu narracyjnego" (s. 11)).

W swoim inicjalnym tekście poświęconym badaniom auto/biograficznym (Kafar 2004) powołałem się na słowa Vincenta Crapanzano, który - opierając się o własne terenowe doświadczenia - wyprowadził wniosek, że ,jakkolwiek obiektywne by się wydawały etnografie, to zawsze będzie w nich ukryty wymiar autobiograficzny" (Crapanzano 1977: 72). Jednocześnie, antycypując nadciągającą zmianę w zakresie lokalnego, polskiego kontekstu waloryzowania tego, co osobiste w przestrzeni eksploracji naukowych, przestrzegałem przed nieuzasadnionym wtłaczaniem różnorakich aspektów konfesyjności badaczy w realizowane przez nich projekty. Przypadek Iwony Kabzińskiej jest dla mnie wyjątkowym przykładem niemożności ucieczki przed Sobq wtedy, gdy autentycznie czujemy się cząstką badanego świata, jest więc przykładem ze wszech miar wyważonego uprawiania antropologii „z człowiekiem w środku” (Wejland 2010b: 156); ponadto jest też znakomitym, godnym naśladowania przykładem jak najdelikatniejszego niwelowania solipsystycznych zakusów na rzecz mądrego korzystania z zasobów rozumienia Siebie oraz Innych, poprzez czerpanie ze złóż tkwiących w narracyjnym/opowieściowym odbiorze (i kreacji) rzeczywistości. „W tej perspektywie badawczej - jak trafnie ujęła to Danuta Urbaniak-Zając, analizując „Nienawidzę tej szkoły"... pod kątem empirycznym - uzasadnieniem dla formułowanych twierdzeń nie jest ani częstotliwość występowania danych sytuacji i zachowań, ani zróżnicowanie ich kontekstów, lecz wartości - etyczny wymiar warunków życia i działania”, umożliwiający „pełniejszy rozwój człowieka” (s. 14).

\footnotetext{
18 Termin „myślenie z opowieścią” (ang. thinking with story) zapożyczam od kanadyjskiego socjologa medycyny, Arthura W. Franka, który w słynnej rozprawie The wounded storyteller. Body, illness, and ethics (1995) uczynił z niego kluczowe narzędzie interpretacyjne, sprowadzające się do traktowania opowieści jako zamkniętej całości o względnym, zależnym od kontekstu użycia polu semantycznym. Za „myśleniem z opowieścią” stoi ideał uwznioślenia życia danego człowieka poprzez uwznioślenie ważnej dla tegoż człowieka opowieści autobiograficznej (por. Kafar 2013b: 59-60). Carolyn Ellis i Arthur P. Bochner rozwijają Frankowską koncepcję, mówiąc o „czuciu z opowieścią” (ang. feeling with story); amerykańscy badacze zakładają, że opowieść autobiograficzna rezonuje nie tylko w „myślach”, lecz także w „ciałach” jej odbiorców (por. Ellis, Bochner 1999).
} 
Na koniec zawrócę do motywu, od którego zacząłem ten szkic, a mianowicie wyłożonej przeze mnie sugestii co do poruszania się w obrębie „uwspólnionej metaperspektywy poznawczej". Ponowię więc pytanie, na czym ta perspektywa miałaby się zasadzać? Gdzie mielibyśmy szukać „zbliżeń”, jednocześnie nie tracąc sprzed oczu „oddaleń"?

Dokonując przeglądu artykułów zawartych w naszej publikacji, odnotowałem pewną prawidłowość. Od razu wypada zaznaczyć, iż stanowi ona bardziej potwierdzenie powszechnie dostępnej, choć stosunkowo rzadko wyrażanej expressis verbis wiedzy na temat badań auto/biograficznych, aniżeli objawia jakąś nieznaną wcześniej o nich prawdę. Otóż, badania typu auto/biograficznego (występujące zarówno w odmianie refleksywnej, jak i innych) żywią się potencjałem stanowiącym własność szeroko definiowanego pogranicza dyscyplinarnego. Truizm to, lecz jakże w tym kontekście wymowny, że ani pedagogika, ani psychologia, ani antropologia, ani socjologia (by wymienić tylko pierwsze z brzegu dyscypliny, gdzie zainteresowania auto/biografiami znajdują się obecnie w pełnym rozkwicie) jako takie nie opierają swej differentia specifica na teoretyczno-metodologicznych przesłankach leżących u źródeł badań auto/biograficznych. Oczywiście, można starać się wyobrazić sobie istnienie każdej $\mathrm{z}$ wymienionych wyżej i wielu innych dyscyplin bez praktykowania podejść auto/biograficznych, jasnym jest natomiast, że rezygnacja $\mathrm{z}$ nich równałaby się $\mathrm{w}$ gruncie rzeczy rezygnacji z bardzo ważnego pola eksploracji określającego w ogóle charakter współczesnych nauk społecznych i humanistycznych. Należy zatem przyjąć, iż wielorako uprawiane badania auto/biograficzne wzbogacają przestrzenie głównych oraz pobocznych prądów dyskursywnych pojedynczych dyscyplin (w szczególnych sytuacjach poznawczych takie prądy także wywołują (patrz Burszta, Kabzińska oraz Urbaniak-Zając w niniejszym tomie)), ale też - co wydaje się mieć nie mniejsze znaczenie heurystyczne - są znakomitym łącznikiem między nimi. (Stąd jak sądzę wzięła się chociażby przywołana przeze mnie już wcześniej w skróconym wariancie opinia Elżbiety Dubas, że oto odmienność między podejściami do badań auto/biograficznych uskutecznianych w etnografii-antropologii i andragogice „nie wyklucza jednak obecności punktów wspólnych, a nade wszystko podobnych wątpliwości i trudności związanych z filozofią takich badań, ich realizacją oraz wynikami teoriopoznawczymi”.) Na ile owocne bywają mariaże międzydyscyplinarne wykorzystujące perspektywę auto/biograficzną obrazuję wespół z Izabelą Kamińską-Jatczak (s. 171-193); tropy przynależne do tej samej kategorii bez kłopotu dają się również odnaleźć w pozostałych artykułach składających się na Edukacyjne wymiary badań biograficznych. Bywa, że owe tropy wyrażane są w sposób dobitnie postulatywny (instruktywną Autorką jest pod tym względem Danuta Urbaniak-Zając, zachęcająca do zapoznania się przez pedagogów z podstawowymi, wykraczającymi poza pedagogikę ustaleniami z zakresu teorii narracji), jawnie inspirujący (filozoficzne inklinacje widać 
m.in. w pracach Burszty, Kafara/Kamińskiej-Jatczak; andragodzy odbywają wycieczki refleksywne - patrz Golonka-Legut/Pryszmont-Ciesielska, pedagodzy społeczni udają się w podróż etnograficzną i vice versa (Kafar/Kamińska-Jatczak)) bądź też utajony, włączając $\mathrm{w}$ to quasi-świadomie bądź nieświadomie uskuteczniane zabiegi przekraczania granic dyscyplinarnych (taki charakter mają m.in. andragogicznie nacechowane wystąpienia Wojciecha Józefa Burszty oraz Iwony Kabzińskiej czy refleksywnie i filozoficznie podbudowane studia Elżbiety Dubas).

Zasygnalizowany przeze mnie trend jest świetnym przyczynkiem do głębszego pochylenia się w przyszłości nad złożonością procesów komunikacyjnych, z jakimi mamy do czynienia, parając się aktywnością naukową. Do ich rozważenia przydatne byłyby m.in. dobrze analitycznie rozpoznane przez Ewę Marynowicz-Hetkę (2015: 181-183) kategorie „pluridyscyplinarności”, „,interdyscyplinarności” i „tranwersalności". Dlaczego - a takie zapewne wrażenie będzie odnosił wystarczająco drobiazgowy odbiorca prezentowanej publikacji - badacze auto/biografii zajmujący się ich edukacyjnymi aspektami posługują się odmiennymi pojęciami, opisując/interpretując/analizując te same doświadczenia/zjawiska? I na odwrót: co sprawia, że zajmując się różnymi doświadczeniami/zjawiskami stosujemy tak samo brzmiące pojęcia, przy dokładnym w nie wglądzie wykazujące się jednak zmiennymi konotacjami semantycznymi? O czym to świadczy i jakie kroki powinniśmy przedsięwziąć, abyśmy w przyszłości mogli nie tylko zabiegać o, ale i długofalowo cieszyć się z rzeczywiście odczuwanej „uwspólnionej metaperspektywy poznawczej"? To pytanie stawiam sobie samemu, Współredaktorkom, Współautorom numeru i wszystkim tym, którzy zdecydowali się zaangażować w jego lekturę.

\section{Bibliografia}

Bowen E. (1954) Return to laugher, New York, Doubleday.

Benedyktowicz Z. (2000) Portrety „obcego”, Kraków, Wydawnictwo Uniwersytetu Jagiellońskiego.

Burszta W. (1994) Yes. Nostalgiczne strefy pamięci, „Polska Sztuka Ludowa. Konteksty", nr 1-2, s. 54-57.

Czaja D. (2002) Życie czyli nieprzejrzystość. Poza antropologię kultury, „Polska Sztuka Ludowa. Konteksty", nr 3-4, s. 6-22.

Czermińska M. (2000) Autobiograficzny trójkąt. Świadectwo, wyznanie i wyzwanie, Kraków, Wydawnictwo Universitas.

Crapanzano V. (1977) On the writing of ethnography, „Dialectical Anthropology”, nr 1, s. 69-73. 
Dubas E. (2009) Refleksja autobiograficzna jako aktywność edukacyjna w kontekście całożyciowego uczenia się w: Aktywność społeczna, kulturalna i oświatowa dorosłych, A. Fabiś, S. Kędziora (red.), Mysłowice-Zakopane, Górnośląska Wyższa Szkoła Pedagogiczna im. Kardynała Augusta Hlonda w Mysłowicach, s. 41-53.

Dubas E. (2011) Jak opracowywać materiał narracyjno-biograficzny? (propozycja) w: Uczenie się z (własnej) biografii, E. Dubas, W. Świtalski (red.), Łódź, Wydawnictwo Uniwersytetu Łódzkiego, s. 241-246.

Dubas E. (2014a) Edukacja w andragogicznych badaniach biograficznych - biografia edukacyjna w: Badanie biografii - źródła, metody, konteksty, R. Skrzyniarz, E. Krzewska, W. Zgłobicka-Gierut (red.), Lublin, Wydawnictwo Episteme, s. 17-31.

Dubas E. (2014b) Czas, biografia i badanie biograficzne - różnorodność kontekstów w andragogicznej perspektywie, „Edukacja Dorosłych”, nr 2, s. 13-27.

Dubas E. (2015a) Andragogiczne badania biografii - zakresy, trudności, etyka badacza (wybrane aspekty) w: Biografie i uczenie się, E. Dubas, J. Stelmaszczyk (red.), Łódź, Wydawnictwo Uniwersytetu Łódzkiego, s. 31-47.

Dubas E. (2015b) Biograficzność w kontekście całożyciowego uczenia się w: Biografie i uczenie się, E. Dubas, J. Stelmaszczyk (red.), Łódź, Wydawnictwo Uniwersytetu Łódzkiego, s. 11-29.

Dubas E., Świtalski W. (red.) (2011a) Uczenie się z (własnej) biografii, Łódź, Wydawnictwo Uniwersytetu Łódzkiego.

Dubas E., Świtalski W. (red.) (2011b) Uczenie się z biografii innych, Łódź, Wydawnictwo Uniwersytetu Łódzkiego.

Ellis C., Bochner A. P. (1999) Bringing emotion and personal narrative into medical social science, „Health”, nr 3, s. 229-237.

Fleck L. (1986) Powstanie i rozwój faktu naukowego. Wprowadzenie do nauki o stylu myślowym i kolektywie myślowym, tłum. M. Tuszkiewicz, wstępem opatrzył Z. Cackowski, Lublin, Wydawnictwo Lubelskie.

Foucault M. (1999) Sobqqpisanie, tłum. M. P. Markowski w: M. Foucault, Powiedziane, napisane. Szaleństwo i literatura, Warszawa, Fundacja Aletheia, s. 303-319.

Frank A. W. (1995) The wounded storyteller. Body, illness, and ethics, Chicago, The University of Chicago Press.

Friedrich P. (1978) Poetry and anthropology, Chicago, Benjamin and Martha Waite Press. 
Friedrich P. (1979) Bastard moons, Chicago, Benjamin and Martha Waite Press.

Kabzińska I. (2007) Sq̨siedztwo ciszy i hałasu, „Tematy z Szewskiej”, nr 1, s. 117-124.

Kabzińska I. (2012) Nadwrażliwi - marginalizowana mniejszość kulturowa w: Ciekawość świata, ludzi, kultury... Księga ofiarowana Profesorowi Ryszardowi Kantorowi z okazji czterdziestolecia pracy naukowej, R. Hołda, T. Paleczny (red.), Kraków, Księgarnia Akademia, s. 121-139.

Kafar M. (2004) Od spotkania do wspólnoty. Autobiograficzny raport z terenu w: Codzienne i niecodzienne. O wspólnotowości w realiach dzisiejszej Łodzi, G. E. Karpińska (red.), Łódź, Polskie Towarzystwo Ludoznawcze, s. 79-101.

Kafar M. (2010) Zwroty zapoznane - zwrot dokonany. Autobiografia w myśleniu etnograficznym i antropologicznym w: „Zwroty” badawcze w humanistyce. Konteksty poznawcze, kulturowe i społeczno-instytucjonalne, Olsztyn, Instytut Filozofii Uniwersytetu Warmińsko-Mazurskiego w Olsztynie.

Kafar M. (red.) (2011) Biografie naukowe. Perspektywa transdyscyplinarna, Łódź, Wydawnictwo Uniwersytetu Łódzkiego.

Kafar M. (red.) (2013a) Scientific biographies. Between the „professional” and „nonprofessional" dimensions of humanistic experiences, Łódź-Kraków, Wydawnictwo Uniwersytetu Łódzkiego, Wydawnictwo Uniwersytetu Jagiellońskiego.

Kafar M. (2013b) W świecie wygnańców, wdów i sierot. O pewnym wariancie antropologii zaangażowanej, Łódź, Wydawnictwo Uniwersytetu Łódzkiego.

Kafar M. (red.) (2016) Auto/biograficzne aspekty praktyk poznawczych, Łódź, Wydawnictwo Uniwersytetu Łódzkiego.

Kapuściński R. (2006) Ten Inny, Kraków, Wydawnictwo Znak.

Klimaszewska J. (1976) Kazimierz Moszyński. Życie i twórczość, Wrocław-WarszawaKraków-Gdańsk, Zakład Narodowy Imienia Ossolińskich, Wydawnictwo Polskiej Akademii Nauk.

MacIntyre A. (1996) Dziedzictwo cnoty. Studium z teorii moralności, tłum A. Chmielewski, Warszawa, PWN.

Marynowicz-Hetka E. (2015) Pedagogizacja życia społecznego - spojrzenie z oddalenia, „Nauki o Wychowaniu. Studia Interdyscyplinarne”, nr 1, s. 178-189.

Mead M. (1966) An anthropologist at work. Writings of Ruth Benedict, New York, Atherton Press. 
Myerhoff B., Ruby J. (1982) Introduction w: A crack in the mirror. Reflexive perspectives in anthropology, J. Ruby (red.), Philadelphia, University of Pennsylvania Press, s. 1-35.

Nowicka E. (2006) Świat człowieka - świat kultury, wydanie nowe, Warszawa, Wydawnictwo Naukowe PWN.

Powdermaker H. (1966) Stranger and friend, New York, Norton.

Ricoeur P. (2005) O sobie samym jako innym, tłum. B. Chełstowski, naukowo opracowała i wstępem opatrzyła M. Kowalska, Warszawa, Wydawnictwo Naukowe PWN.

Rose D. (1982) Occasions and forms of anthropological experience w: A crack in the mirror. Reflexive perspectives in anthropology, J. Ruby (red.), Philadelphia, University of Pennsylvania Press, s. 219-273.

Rose D. (1990) Living the ethnographic life, Newbury Park, Sage.

Tischner J. (2006) Filozofia dramatu, Kraków, Wydawnictwo Znak.

Urbaniak-Zając D. (2009) O znaczeniu teorii i metodyki $w$ badaniach jakościowych (biograficznych) oraz o ich społecznym kontekście, „Pedagogika Kultury”, t. V, s. 43-57.

Urbaniak-Zając D. (2011) Biograficzna perspektywa badawcza w: Uczenie się z (własnej) biografii, E. Dubas, W. Świtalski (red.), Łódź, Wydawnictwo Uniwersytetu Łódzkiego, s. 11-27.

Urbaniak-Zając D. (2014) Studia $w$ doświadczeniu biograficznym absolwentów pedagogiki, „Teraźniejszość - Człowiek - Edukacja”, nr 2, s. 91-106.

Wejland A. P. (2010a) Dyskurs i tożsamość. Opowieści we wspólnocie naukowej w: Okolice socjologicznej tożsamości. Księga poświęcona pamięci Wojciecha Sitka, I. Taranowicz (red.), Wrocław, Wydawnictwo Uniwersytetu Wrocławskiego, s. 155-182.

Wejland A. P. (2010b) Latem w parku. Epifanie codzienności w: Lato w mieście. Różne oblicza kultury, R. Godula-Węcławowicz (red.), Kraków-Warszawa, Instytut Archeologii i Etnologii Polskiej Akademii Nauk, s. 145-162.

Wejland A. P. (2016) Spojrzeć na świat jak antropolog. Wyzwanie autobiograficzne w: Auto/biograficzne aspekty praktyk poznawczych, M. Kafar (red.), Łódź, Wydawnictwo Uniwersytetu Łódzkiego, s. 33-47. 